\title{
HUBUNGAN SIKAP, DUKUNGAN KELUARGA DAN PERAN TENAGA KESEHATAN DENGAN PEMBERIAN IMUNISASI TETANUS TOXOID PADA IBU HAMIL DI PUSKESMAS SEKIP PALEMBANG TAHUN 2018
}

\author{
Rini Gustina Sari \\ Universitas Kader Bangsa
}

\section{Informasi Artikel :}

Diterima : $\quad$ Maret 2019

Disetujui : Juni 2019

\section{"Korespondensi Penulis :} gustinasari15@gmail.com

\begin{abstract}
A B S T R A K
Menurut World Health Organization (WHO) menunjukkan bahwa kematian akibat Tetanus Neonatorum di Negara-negara berkembang adalah 135 kali lebih tinggi daripada Negara maju. Tahun 2011 dilaporkan kasus Tetanus di seluruh dunia sebanyak 14.132 kasus dengan kematian terjadi pada 61.000 ibu hamil. Di Indonesia, masih ditemukan banyak kasus tetanus neonatorum terutama daerah dengan cakupan persalinan oleh tenaga kesehatan yang rendah. Tujuan penelitian mengetahui hubungan sikap, dukungan keluarga dan peran petugas kesehatan dengan pemberian imunisasi tetanus toxoid pada ibu hamil di Puskesmas Sekip Palembang Tahun 2018. Penelitian jenis penelitian adalah bersifat kuantitatif dengan menggunakan metode survey analitik dengan pendekatan cross sectional. Subjek penelitiannya adalah semua ibu hamil K1 yang datang ke Puskesmas Sekip menggunakan kuisioner dengan jumlah 67 responden. Hasil penelitian didapatkan ibu hamil dengan sikap positif sudah mengerti akan tujuan/manfaat dan efek samping mengenai pemberian imunisasi Tetanus Toxoid pada ibu hamil sehingga ibu hamil cenderung bersikap positif. ibu hamil dan orang orang yang berhubungan dekat dengan ibu hamil yang memberikan dukungan positif cenderung dilakukan imunisasi. Peran petugas kesehatan yang memiliki tugas untuk meningkatkan kesehatan masyarakat, termasuk juga petugas kesehatan imunisasi Tetanus Toksoid yang memiliki tugas untuk mengajak ibu hamil cenderung melakukan imunisasi agar terhindar dari penyakit infeksi tetanus yang dapat menyebabkan kematian bagi ibu dan bayi yang tidak melakukan imunisasi Tetanus selama kehamilan.
\end{abstract}

Kata Kunci : Imunisasi Tetanus Toxoid, Sikap, Dukungan keluarga, Peran tenaga kesehatan

\begin{abstract}
According to the World Health Organization (WHO) shows that deaths from Tetanus Neonatorum in developing countries are 135 times higher than developed countries. In 2011 there were 14,132 cases of Tetanus worldwide reported with deaths occurring in 61,000 pregnant women. In Indonesia, there are still many cases of tetanus neonatorum, especially in areas with low coverage of deliveries by health workers. The research objective was to find out the relationship between attitudes, family support and the role of health workers by giving tetanus toxoid immunization to pregnant women at Palembang Sekip Health Center in 2018. The research was quantitative in nature using analytical survey method with cross sectional approach. The research subjects were all Kl pregnant women who came to the Sekip Health Center using a questionnaire with a total of 67 respondents. The results showed that pregnant women with a positive attitude already understood the purpose / benefits and side effects of giving Tetanus Toxoid immunization to pregnant women so that pregnant women tended to be positive. pregnant women and people who are in close contact with pregnant women who provide positive support tend to be immunized. The role of health workers who have the duty to improve public health, including health workers Tetanus Toksoid immunization who has the task of inviting pregnant women to do immunizations to avoid tetanus infection which can cause death for mothers and infants who do not do Tetanus immunization during pregnancy.
\end{abstract}

Keywords: Tetanus Toxoid immunization, attitude, family support, role of health workers 


\section{PENDAHULUAN}

World Health Organization (WHO) menghitung insidensi secara global kejadian tetanus di dunia secara kasar berkisar antara $0,5-$ 1 juta kasus dan Tetanus Neonatorum (TN) terhitung sekitar $50 \%$ dari kematian akibat tetanus di negara - Negara berkembang. Perkiraan insidensi tetanus secara global adalah 18 per 100.000 populasi per tahun (Wijayanti, 2013).

World Health Organization (WHO) menunjukkan bahwa kematian akibat Tetanus Neonatorum di negara-negara berkembang adalah 135 kali lebih tinggi daripada Negara maju. Tahun 2011 dilaporkan kasus Tetanus di seluruh dunia sebanyak 14.132 kasus dengan kematian terjadi pada 61.000 ibu hamil (Angelina, 2013 ).

Menurut Departemen Kesehatan angka kematian bayi di Indonesia yang disebabkan oleh penyakit tetanus neonatorum masih tetap tinggi. Menurut Badan Kependudukan dan Keluarga Berencana Nasional (BKKBN) penyebab langsung kematian ibu di Indonesia adalah pendarahan, hipertensi saat kehamilan, dan infeksi. Menurut Riset Kesehatan Dasar penyebab kematian bayi ini salah satunya adalah tetanus Neonatorum (Kemenkes, 2016).

Imunisasi Tetanus merupakan salah satu solusi untuk mencegah terjadinya Tetanus Neonatorum. Ibu hamil penting mendapat imunisasi untuk mencegah terjadi Tetanus pada ibu dan bayinya. Meskipun imunisasi tetanus pada ibu hamil dinilai sangat penting sebagai bentuk pencegahan tetanus pasca persalinan, maupun pada bayi yang dilahirkan sang ibu, pemanfaatan imunisasi Tetanus Toxoid (TT) pada ibu hamil dinilai masih kurang optimal (Pratiwi, 2013).

Rendahnya cakupan Tetanus Toxoid (TT) antara lain disebabkan oleh pengetahuan ibu hamil tentang imunisasi Tetanus Toxoid (TT) masih rendah serta sikap yang belum mendukung untuk melaksanakan praktek imunisasi (Mislianti, 2012).

Cakupan imunisasi Tetanus Toxoid (TT) ibu hamil di Provinsi Sumatera Selatan Tahun 2016 masih dibawah target yaitu $90 \%$, ibu hamil yang dilakukan imunisasi TT2+ sebanyak 110.220 orang $(60,87 \%)$ ( Pusdatin , 2016 ).

Di Kota Palembang pada Tahun 2015 untuk cakupan TT 2+ sebesar 109,85\% ( ProfilDinkes Kota Palembang, 2015 ). Di Puskesmas Sekip, pada tahun 2016 ibu hamil yang diimunisasi TT2+ sebanyak 604 orang ( $96,2 \%$ ). Sedangkan pada tahun 2017 sebanyak428 orang $(99,07 \%)$

Berdasarkan data yang diperoleh dari Puskesmas Sekip pada tahun 2016 mengenai kunjungan ibu hamil untuk melakukan imunisasi tetanus toxoid (TT) yaitu, jumlah ibu hamil 628 orang, jumlah ibu hamil yang diimunisasi TT2+sebanyak 604 orang (96,2\% ). Sedangkan jumlah ibu hamil pada Tahun 2017 sebanyak 432 orang, jumlah ibu hamil yang diimunisasi TT2+ sebanyak 428 orang $(99,07 \%)$ ( Puskesmas Sekip, 2017).

Adapun faktor - faktor yang mempengaruh iimunisasi tetanus toxoid pada ibu hamil adalah pengetahuan, sikap, kepercayaan, tradisi orang / masyarakat disekelilingnya, lingkungan fisik, ketersediaan sarana dan prasarana, sikap, perilaku tenaga kesehatan (Notoatmojo, 2003).

Berdasarkan data diatas diambil judul

"Hubungan Sikap, Dukungan Keluarga dan Peran Tenaga Kesehatan dengan Pemberian Imunisasi Tetanus Toxoid ( TT ) pada Ibu Hamil di Puskesmas Sekip Palembang Tahun 2018 “.

\section{METODE PENELITIAN}

Penelitian ini menggunakan metode survei analitik dengan rancangan Cross Sectional dimana variabel sikap, dukungan keluarga dan peran tenaga kesehatan serta imunisasi tetanus toxoid ( TT ) hanya diobservasi dan diambil satu kali saja dalam waktu bersamaan pada saat penelitian (Notoatmodjo, 2005)

Populasi adalah keseluruhan objek penelitian atau objek yang diteliti ( Sulityawati, 2011 )

Populasi dalam penelitian ini adalah seluruh ibu hamil yang ada di wilayah kerja Puskesmas Sekip Palembang Tahun 2018 sebanyak 45 orang.

Analisa Univariat Dilakukan untuk mengetahui distribusi frekuensi, yang meliputi variable dependen pemberian imunisasi tetanus toxoid pada ibu hamil dan variable independen sikap, dukungan keluarga dan peran tenaga kesehatan untuk menggabungkan kategori jika diperlukan ( Notoatmojo, 2010 ).

Analisa univariat pada penelitian dilakukan terhadap tiap variabel penelitian yaitu variabel dependen (Imunisasi Tetanus Toxoid) dan variabel independen (sikap, dukungan keluarga dan peran tenaga kesehatan) yang dianalisis dengan menggunakan tabel distrbusi frekuensi. 


\section{HASIL PENELITIAN}

\section{Pemberian imunisasi Tetanus Toxoid}

Pemberian imunisasi Tetanus Toxoid dikategorikan menjadi dua yaitu Ya (Jika Ibu dilakukan imunisasi ) dan Tidak (jika tidak dilakukan imunisasi ) dapat dilihat pada tabel 1:

Tabel 1 Distribusi Frekuensi Responden Berdasarkan Pemberian imunisasi Tetanus Toxoid Di Puskesmas Sekip Palembang Tahun 2018

\begin{tabular}{lllc}
\hline $\begin{array}{c}\text { N } \\
\mathbf{0}\end{array}$ & $\begin{array}{c}\text { Pemberian } \\
\text { Imunisasi Tetanus } \\
\text { Toxoid }\end{array}$ & n & $\begin{array}{c}\text { Persentase } \\
(\mathbf{\%})\end{array}$ \\
\hline 1. & Ya & 59 & 88,1 \\
2. & Tidak & 8 & 45 \\
\hline Jumlah & $\mathbf{6 7}$ & $\mathbf{1 0 0}$ \\
\hline
\end{tabular}

Dari tabel 1 didapatkan ibu hamil yang pemberian imunisasi tetanus toxoid sebesar 59 $(88,1 \%)$ dan ibu yang tidak dilakukan imunisasi yaitu sebesar $8(11,9 \%)$ responden.

Sikap

Tabel 2 Distribusi Frekuensi Responden Berdasarkan Sikap Di Puskesmas Sekip Palembang Tahun 2018

\begin{tabular}{lclc}
\hline No & Sikap & n & Persentase (\%) \\
\hline 1. & Positif & 55 & 82,1 \\
2. & Negative & 12 & 17,9 \\
\hline Jumlah & $\mathbf{6 7}$ & $\mathbf{1 0 0}$ \\
\hline
\end{tabular}

Dari tabel 2 diketahui ibu hamil dengan sikap positif lebih besar yaitu 55 orang $(82,1 \%)$, dibandingkan responden ibu hamil dengan sikap negatif yaitu sebanyak 12 orang $(17,9 \%)$.

\section{Dukungan Keluarga}

Tabel 3 Distribusi Frekuensi Responden Berdasarkan Dukungan Keluarga Ibu Di Puskesmas Sekip Palembang Tahun 2018

\begin{tabular}{lclc}
\hline $\begin{array}{c}\text { N } \\
\text { o }\end{array}$ & $\begin{array}{c}\text { Dukungan } \\
\text { Keluarga }\end{array}$ & n & $\begin{array}{c}\text { Persentase } \\
(\mathbf{\%})\end{array}$ \\
\hline 1. & Mendukung & 53 & 79,1 \\
2. & Tidak mendukung & 14 & 20,9 \\
\hline Jumlah & $\mathbf{6 7}$ & $\mathbf{1 0 0}$ \\
\hline
\end{tabular}

Dari tabel 3 didapatkan ibu hamil dengan dukungan keluarga lebih besar yaitu 53orang $(79,1 \%)$, dibandingkan responden ibu hamil dengan keluarga yang tidak mendukung yaitu sebanyak 14 orang $(20,9 \%)$.

\section{Peran Tenaga Kesehatan}

Tabel 4 Distribusi Frekuensi Responden Berdasarkan Peran Tenaga
Kesehatan Di Puskesmas Sekip Palembang Tahun 2018

\begin{tabular}{lllc}
\hline No & $\begin{array}{c}\text { Peran } \\
\text { Tenaga } \\
\text { Kesehatan }\end{array}$ & n & $\begin{array}{c}\text { Persentase } \\
(\mathbf{\%})\end{array}$ \\
\hline 1. & Aktif & 57 & 85 \\
2. & Pasif & 10 & 15 \\
\hline Jumlah & $\mathbf{6 7}$ & $\mathbf{1 0 0}$ \\
\hline \multicolumn{2}{c}{ Ibu hamil } & dengan & peran tenaga
\end{tabular}

kesehatan aktif yaitu 57 orang ( $85 \%)$ sedangkan responden ibu hamil dengan peran tenaga kesehatan yang pasif yaitu sebanyak 10 orang $(15 \%)$.

\section{b. Analisa Bivariat}

Analisis ini dilakukan untuk mengetahui hubungan variabel independen yaitu Sikap, Dukungan Keluarga dan Peran Tenaga Kesehatan dengan variabel dependen yaitu Pemberian imunisasi Tetanus Toxoid. Penelitian dilakukan untuk melihat apakah ada hubungan antara variabel independen dan variabel dependen, dengan menggunakan uji Chi-Square pada $\alpha=0,05$ dan $\mathrm{df}=1$, bila $\mathrm{p}$ Value $\leq 0,05$ berarti ada hubungan yang bermakna jika $p$ Value $>0,05$ berarti tidak ada hubungan yang bermakna.

Hubungan antara Sikap dengan Pemberian Imunisasi Tetanus Toxoid Di Puskesmas Sekip Palembang Tahun 2018 Tabel 5 Distribusi Responden Berdasarkan Sikap Dengan Pemberian Imunisasi Tetanus Toxoid Di Puskesmas Sekip Palembang Tahun 2018

\begin{tabular}{|c|c|c|c|c|c|c|c|c|}
\hline \multirow{3}{*}{ No } & \multirow{3}{*}{ Sikap } & \multicolumn{4}{|c|}{ Pemb Imunisasi TT } & \multirow{2}{*}{\multicolumn{2}{|c|}{ Jumlah }} & \multirow{3}{*}{$\begin{array}{c}\text { Tingkat } \\
\text { Kemakn } \\
\text { aan }\end{array}$} \\
\hline & & \multicolumn{2}{|c|}{ Ya } & \multicolumn{2}{|r|}{ Tidak } & & & \\
\hline & & $\mathbf{n}$ & $\%$ & $\mathbf{n}$ & $\%$ & $\mathbf{N}$ & $\%$ & \\
\hline 1. & Positif & 52 & 94,5 & 3 & 5,5 & 55 & 100 & \multirow{3}{*}{$\begin{array}{c}\mathrm{P} \text { value }= \\
0,003\end{array}$} \\
\hline 2. & Negative & 7 & 58,3 & 5 & 41,7 & 12 & 100 & \\
\hline & Jumlah & 59 & - & 8 & - & 67 & 100 & \\
\hline
\end{tabular}

Dari table 4 diketahui bahwa dari 55 responden ibu hamil, yang memiliki sikap positif dilakukan imunisasi tetanus toxoid sebanyak 52 responden $(94,5 \%)$, responden yang memiliki sikap positif tidak dilakukan imunisasi tetanus toxoid sebanyak 3 responden (5,5\%). Dari 12 responden yang memiliki sikap negative dilakukan imunisasi tetanus toxoid sebanyak 7 responden $(58,3 \%)$, responden yang memiliki sikap negatif tidak dilakukan imunisasi tetanus toxoid sebanyak 5 responden $(41,7 \%)$

Dari uji Chi-square diperoleh $\rho$ value $0,003<\alpha 0,005$ yang artinya ada hubungan 
yang bermakna antara sikap dengan pemberian imunisasi tetanus toxoid di Puskesmas Sekip Palembang Tahun 2018.

Hubungan antara Dukungan Keluarga dengan Pemberian Imunisasi Tetanus Toxoid Di Puskesmas Sekip Palembang Tahun 2018

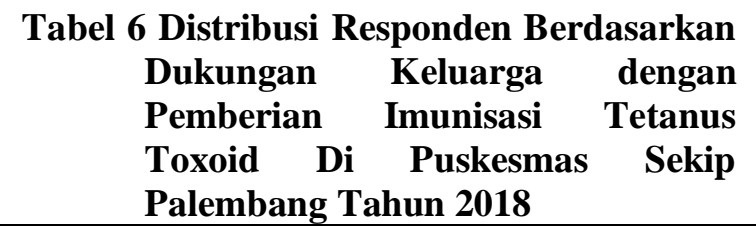
Pemb Imunisasi TT

\begin{tabular}{llllllllll} 
N & Duk. Keluarga & & Ya & & Tidak & Jumlah & $\begin{array}{c}\text { Tingkat } \\
\text { Kemak- } \\
\text { naan }\end{array}$ \\
\cline { 2 - 7 } & & & & & & & & & \\
\hline
\end{tabular}
1. Mendukung
$\begin{array}{llllll}51 & 96,2 & 2 & 3,8 & 53 & 100\end{array}$
2. Tidak mendukung
857
$\begin{array}{lllll}6 & 62,9 & 14 & 100 & \text { P Value }\end{array}$ $=0,001$

\section{Jumlah}

59

8

$67 \quad 100$

Dari tabel 6 diketahui dari 53 responden yang mendapat dukungan keluarga dilakukan imunisasi tetanus toxoid berjumlah 51 responden $(96,2 \%)$ lebih besar dari responden yang mendapat dukungan keluarga tidak dilakukan imunisasi tetanus toxoid berjumlah 2 responden $(3,8 \%)$. Responden yang tidak mendapat dukungan keluarga dilakukan imunisasi tetanus toxoid 8 responden $(57,1 \%)$ lebih besar dari responden yang tidak dilakukan imunisasi tetanus toxoid berjumlah 6 responden $(42,9 \%)$

Dari uji Chi-square diperoleh $\rho$ value $0,001<\alpha 0,05$ yang artinya ada hubungan yang bermakna antara dukungan keluarga dengan pemberian imunisasi tetanus toxoid di Puskesmas Sekip Palembang Tahun 2018.

Hubungan antara Peran Tenaga Kesehatan dengan Pemberian Imunisasi Tetanus Toxoid Di Puskesmas Sekip Palembang Tahun 2018

Tabel 7 Distribusi Responden Berdasarkan

Peran Tenaga Kesehatan dengan

Pemberian Imunisasi Tetanus

Toxoid Di Puskesmas Sekip

Palembang Tahun 2018

\begin{tabular}{|c|c|c|c|c|c|c|c|c|}
\hline \multirow{3}{*}{$\mathbf{N}$} & \multirow{3}{*}{$\begin{array}{c}\text { Peran Tenaga } \\
\text { Kesehatan }\end{array}$} & \multicolumn{4}{|c|}{ Pemb Imunisasi TT } & \multirow{2}{*}{\multicolumn{2}{|c|}{ Jumlah }} & \multirow{3}{*}{$\begin{array}{l}\text { Tingkat } \\
\text { Kemak- } \\
\text { naan }\end{array}$} \\
\hline & & \multicolumn{2}{|c|}{ Ya } & \multicolumn{2}{|c|}{ Tidak } & & & \\
\hline & & $\mathbf{n}$ & $\%$ & $\mathbf{n}$ & $\%$ & $\mathbf{N}$ & $\%$ & \\
\hline . & Aktif & 54 & 947 & 3 & 53 & 57 & 100 & P Value \\
\hline 2. & $\mathrm{~Pa}$ & 5 & 50 & 5 & 50 & 10 & 100 & \\
\hline & Jumlah & 59 & & 8 & & 67 & 100 & \\
\hline
\end{tabular}

Dari tabel 7 diketahui ibu hamil dengan peran tenaga kesehatan aktif yaitu 57 orang $(85,1 \%)$ sedangkan responden ibu hamil dengan peran tenaga kesehatan yang pasif yaitu sebanyak 10 orang $(14,9 \%)$ sedangkan analisis bivariatbahwa dari 57 responden dengan peran tenaga kesehatan yang aktif melakukan pemberian imunisasi tetanus toxoid berjumlah 54 orang $(94,7 \%)$ dan yang tidak melakukan pemberian imunisasi tetanus toxoid berjumlah 3 orang $(5,3 \%)$ sedangkan responden dengan peran tenaga kesehatan yang pasif melakukan imunisasi tetanus toxoid sebanyak 5 responden $(50 \%)$ dan responden dengan peran peran tenaga kesehatan pasif tidak melakukan pemberian imunisasi berjumlah 5 orang $(50 \%)$.

Dari hasil uji chi-square di peroleh $\rho$ value $0,001<\alpha \quad 0,05$ yang artinya ada hubungan yang bermakna antara peran tenaga kesehatan dengan pemberian imunisasi tetanus toxoid di Puskesmas Sekip Palembang Tahun 2018.

\section{PEMBAHASAN}

\section{Pemberian Imunisasi Tetanus Toxoid}

Imunisasi Tetanus Toxoid adalah proses untuk membngun kekebalan sebagai upaya pencegahan terhadap infeksi tetanus ( Idanati, 2005 ). Ibu hamil adalah ibu yang mengandung mulai trimester I sampai dengan trimester III ( Kemenkes, 2010 )

Dalam penelitian ini, Pemberian imunisasi Tetanus Toxoid dikategorikan menjadi dua yaitu Ya (Jika Ibu dilakukan imunisasi) dan Tidak (jika tidak dilakukan imunisasi). Hasil penelitian ini didapatkan distribusi responden dengan Berdasarkan analisa univariat dari 67 responden ibu hamil yang dilakukan pemberian imunisasi tetanus toxoid mempunyai proporsi lebih besar yaitu $59(88,1 \%)$ dibandingkan responden ibu yang tidak dilakukan imunisasi yaitu sebanyak 8 ( $11,9 \%$ ) responden. 


\section{Sikap dengan Pemberian Imunisasi Tetanus Toxoid}

Sikap adalah organisasi pendapat, keyakinan seseorang mengenai objek atau situasi yang relatif ajeg, yang disertai adanya perasaan tertentu, dan memberikan dasar pada orang tersebut untuk membuat respons atau berpenilaku dalam cara tertentu yang dipilihnya (Walgito, 2001).

Berdasarkan hasil analisis univariat 67 responden yang memiliki sikap positif sejumlah $55(82,1 \%)$ orang dan yang memiliki sikap negatif sejumlah $12(17,9 \%)$ orang. Hasil analisis bivariat hubungan sikap dengan pemberian imunisasi tetanus toxoid diketahui bahwa dari 67 responden ibu hamil, yang memiliki sikap positif dilakukan imunisasi tetanus toxoid sebanyak 52 orang $(94,5 \%)$ lebih besar dibandingkan dengan responden yang memiliki sikap negatifdilakukan imunisasi tetanus toxoid sebanyak 7 orang $(58,3 \%)$

Dari hasil uji chi-square di peroleh $\rho$ value $0,003<\alpha \quad 0,05$ yang artinya ada hubungan yang bermakna antara sikap dengan pemberian imunisasi tetanus toxoid.

Hasil ini sesuai dengan penelitian di Puskesmas Meutulang bahwa 26 responden yang Sikap Positifada 18 responden $(69,2 \%)$ yang imunisasi tetanus toxoid. Sedangkan dari 28 responden dengansikap negatif ada 6 responden $(21,42 \%)$ pemberian imunisasi tidak mendapat danyang mendapat terhadap Toksoid pada masa kehamilan. Dari analitik statistic Chi-Square Test diperoleh $\mathrm{p}$ value $=0,001$ dengan kemaknaan $(p<0,05)$, yang berarti bahwa ada pengaruhbermakna antara Sikap imunisasi (TT)Tetanus Toksoid Pada Masa Kehamilan diPuskesmas Meutulang Kecamatan Panton Reu ( Syarifah, 2012).

Sebagai seorang bidan, kontribusi yang dapat kita berikan diantaranya adalah pemberian KIE mengenai pengertian, tujuan/manfaat dan efek samping mengenai pemberian imunisasi Tetanus Toxoid pada ibu hamil sehingga diharapkan sikap positif akan dihasilkan oleh individu tersebut.

Peneliti berasumsi setelah membandingkan hasil penelitian yang dilakukan oleh peneliti terhadap teori dan hasil penelitian terkait ada hubungan sikap dengan pemberian imunisasi tetanus toxoid karena pemberian imunisasi adalah tindakan medis, sehingga membutuhkan persetujuan/ kesediaan ibu.

\section{Dukungan Keluarga dengan Pemberian Imunisasi Tetanus Toxoid}

Peran keluarga dalam pemberian imunisasi tetanus toxoid sangat penting, keluarga sebagai orang -orang yang paling dekat dengan ibu hamil harus memotivasi ibu hamil serta mendukung ibu hamil baik secara moril maupun materiil. Dukungan suami, keluarga sangat memberikan motivasi dalam pemberian imunisasi pada ibu hamil (Eko, K.P,2009)

Dari hasil analisis univariat dari 67 responden dapat dilihat dari 67 responden, ibu hamil dengan dukungan keluarga yaitu 53 orang $(79,1 \%)$ sedangkan responden ibu hamil dengan anggota keluarga yang tidak mendukung yaitu sebanyak 14 orang (20,9\%). Sedangkan analisis bivariat diketahui dari 53 responden yang mendapat dukungan keluargadilakukan imunisasi tetanus toxoid berjumlah 51responden $(96,2 \%)$ lebih besar dari responden yang mendapat dukungan keluarga tidak dilakukan imunisasi tetanus toxoid berjumlah 2 responden $(3,8 \%)$. Responden yang tidak mendapat dukungan keluarga dilakukan imunisasi tetanus toxoid 8 responden $(57,1 \%)$ lebih besar dari responden yang tidak dilakukan imunisasi tetanus toxoid berjumlah 6 responden $(42,9 \%)$.

Dari hasil uji chi-square di peroleh $\rho$ value $0,001<\alpha \quad 0,05$ yang artinya ada hubungan yang bermakna antara dukungan keluarga dengan pemberian imunisasi tetanus toxoid.

Hasil ini sesuai dengan penelitian penelitian Mislianti, ada hubungan antara dukungan keluarga dengan imunisasi tetanus toxoid, dikarenakan hasil penelitian menunjukkan responden mendapatkan dukungan keluarga ( $\mathrm{p}$ value 0,000 OR 7,5) (Mislianti, 2012 )

Sebagai seorang bidan, kontribusi yang dapat kita berikan diantaranya adalah pemberian KIE mengenai pengertian, tujuan/manfaat dan efek samping mengenai pemberian imunisasi Tetanus Toxoid pada ibu hamil dan orang orang yang berada di sekelilingnya, terutama orang orang yang berhubungan dekat dengan ibu hamil tersebut sehingga diharapkan dukungan positif yang ada pada orang terdekat bisa membuat ibu hamil bersedia dilakukan imunisasi. 


\section{Peran Tenaga Kesehatan dengan Pemberian Imunisasi Tetanus Toxoid}

Berdasarkan hasil analisis univariat dari 67 responden ibu hamil dengan peran tenaga kesehatan aktif yaitu 57orang $(85,1 \%)$ sedangkan responden ibu hamil dengan peran tenaga kesehatan yang pasif yaitu sebanyak 10 orang ( $14,9 \%$ ) sedangkan analisis bivariatbahwa dari 57 responden dengan peran tenaga kesehatan yang aktif melakukan pemberian imunisasi tetanus toxoid berjumlah 54 orang $(94,7 \%)$ dan yang tidak melakukan pemberian imunisasi tetanus toxoid berjumlah 3 orang $(5,3 \%)$ sedangkan responden dengan peran tenaga kesehatan yang pasif melakukan imunisasi tetanus toxoid sebanyak 5 responden (50\%) dan responden dengan peran peran tenaga kesehatan pasif tidak melakukan pemberian imunisasi berjumlah 5 orang (50\%)

Dari hasil uji chi-square di peroleh $\rho$ value $0,001<\alpha 0,05$ yang artinya ada hubungan yang bermakna antara peran tenaga kesehatan dengan pemberian imunisasi tetanus toxoid.

Hal ini sesuai dengan hasil uji statistic penelitian Diah $\mathrm{T}$ ada hubungan antara peran tenaga kesehatan dan pemberian imunisasi tetanus toxoid pada ibu hamil dikarenakan 93 responden yang diteliti, $77(82,7 \%)$ memiliki peran tenaga kesehatan yang aktif. Uji statistik menunjukkan pvalue $0,001 \leq$ $\alpha=0,05$ dinyatakan ada hubungan peran tenaga kesehatan dengan pemberian imunisasi TT (Diah T , 2016).

Petugas kesehatan memiliki tugas untuk meningkatkan kesehatan masyarakat, termasuk juga petugas kesehatan imunisasi Tetanus Toksoid yang memiliki tugas untuk mengajak masyarakat untuk melakukan imunisasi agar terhindar dari penyakit infeksi tetanus yang dapat menyebabkan kematian bagi ibu dan bayi yang tidak melakukan imunisasi Tetanus selama kehamilan.

\section{KESIMPULAN}

Berdasarkan hasil penelitian dan analisa data serta pembahasan yang telah dilakukan pada 67 responden, dapat ditarik kesimpulan Ada hubungan yang bermakna antara sikap dengan pemberian imunisasi tetanus toxoid di Puskesmas sekip palembang tahun 2018 dengan $P$ value $=$ 0,003 , Ada hubungan yang bermakna antara dukungan keluarga dengan pemberian imunisasi tetanus toxoid di Puskesmas sekip palembang tahun 2018 dengan $P$ value $=0,001$, Ada hubungan yang bermakna antara peran tenaga kesehatan dengan pemberian imunisasi tetanus toxoid di Puskesmas sekip palembang tahun 2018 dengan $P$ value $=0,001$

\section{SARAN}

1. Bagi Puskesma Sekip Palembang

Diharapkan Puskesmas Sekip Palembang secara berkala melakukan evaluasi pelayanan antenatal care yang sudah diberikan demi tercapainya pelayanan yang berkualitas.

\section{Bagi Universitas Kader Bangsa}

Diharapkan hasil penelitian ini dapat digunakan sebagai kepuastakaan untuk menambah wawasan mahasiswa Program Studi Diploma IV Universitas Kader Bangsa Palembang yang akan datang.

\section{Bagi Peneliti yang akan datang}

Diharapkan kepada peneliti yang akan datang untuk mencari faktor-faktor lain yang mungkin berhubungan dengan pemberian imunisasi tetanus toxoid sehingga semakin banyak literatur yang dapat memberikan tambahan pengetahuan yang berhubungan dengan kebidanan.

\section{DAFTAR PUSTAKA}

DinasKesehatanProvinsi Sumatera Selatan. Profil Kesehatan Provinsi Sumatera Selatan Tahun 2015

DinasKesehatanProvinsi Sumatera Selatan. ProfilKesehatan Kota Palembang Tahun 2016

KemenkesRI ,2016. ProfilKesehatan Indonesia Tahun 2015. Jakarta: Kemenkes RI.

Kemenkes RI, 2017. Data danInformasiProfilKesehatan Indonesia 2016, Jakarta: Kemenkes RI

Mochtar, Rustam, 2013, SinopsisObstetri,Jakarta, PenerbitBukuKedokteran : EGC

Manuaba, Ida BagusGde, dkk. 2008. BukuPengantarObtetri. Jakarta : EGC

Maryunani, $\quad 2010$. BiologiReproduksiDalamKebidanan. Jakarta : Trans Info Media

Muslihatu, Wafi Nur, dkk. 2010. Dokumentasi Kebidanan. Yogyakarta: Fitramaya

.Asuhan Kebidanan Bayi dan Neonatus.Yogyakarta: Fitramaya 
Norma, Nita, dkk, 2013.Asuhan Kebidanan Patologi Teoridan Tinjauan Kasus.Yogyakarta :Nuha Medika

Rukiyah, AY.,\&Yulianti, L. 2013. Konsep Kebidanan. Jakarta: Trans Info Media.

Rukiyah, Ai Yeyeh, dkk.2010. Asuhan Kebidanan 4 Patologi.Jakarta : Trans Info Media

Sunaryo, 2002. Psikologi untuk Keperawatan.Jakarta : EGC

Sulistyawati, Ari. 2011. Asuhan Kebidanan Pada Masa Kehamilan. Jakarta :Salemba Medika

Sofiian, A, 2011.SipnosisObstetri, Edisi 3, Jilid 1. Jakarta : EGC

Winkjosastro, Hanifa, dkk. 2009. Ilmu kebidanan. Jakarta :Yayasan Bina Pustaka

Sarwono Prawirohardjo. 2011. Ilmu kebidanan. Jakarta :Yayasan Bina Pustaka. 
